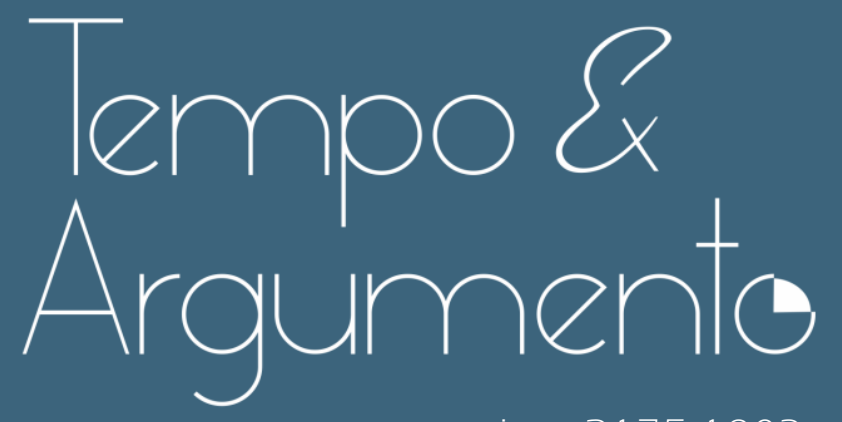

e-issn 2175-1803

Nem tão "cristianizado" assim: apontamentos sobre as eleições de 1950 em Santa Catarina e a vitória de Getúlio Vargas

- Camilo Buss Araujo

Doutor em História Social pela Universidade Estadual de Campinas (UNICAMP).

Professor na Universidade Federal de Santa Catarina (UFSC).

Florianópolis, SC - BRASIL

lattes.cnpq.br/9668045077094140

camilobuss@gmail.com

(D) orcid.org/0000-0002-7517-2136

Para citar este artigo:

ARAUJO, Camilo Buss. Nem tão "cristianizado" assim: apontamentos sobre as eleições de 1950 em Santa Catarina e a vitória de Getúlio Vargas. Tempo e

Argumento, Florianópolis, v. 12, n. 29, e0207, jan./abr. 2020

doi http://dx.doi.org/10.5965/2175180312292020e0207

Recebido: 10/03/2019

Aprovado: 15/09/2019 


\title{
Nem tão "cristianizado" assim: apontamentos sobre as eleições de 1950 em Santa Catarina e a vitória de Getúlio Vargas
}

\begin{abstract}
Resumo
A vitória na eleição de 1950 trouxe Getúlio Vargas de volta ao comando do executivo nacional cinco anos após o fim do Estado Novo. Em um pleito eivado de polêmica, o xadrez político nacional balizou as disputas políticas locais. PTB, PSD e UDN buscaram pragmaticamente construir alianças regionais e oferecer bons palanques para seus presidenciáveis nos estados. Após a divulgação dos resultados das urnas e a vitória do líder trabalhista, reconhecidos políticos e jornalistas manifestaram sua inconformidade, responsabilizando o PSD pelo retorno do "ex-ditador". A pequena votação de Cristiano Machado, candidato pessedista, teria sido motivada pela infidelidade do partido, que abandonara sua candidatura oficial em favor de Vargas. A esse movimento deu-se no nome de "cristianização". Santa Catarina, em princípio, teria sido um desses casos, no qual o PSD local deslocara seu apoio ao candidato trabalhista. Todavia, ao observar as articulações e alianças políticas regionais, as estratégias de campanha e a votação no estado discriminada por município, é possível observar que o movimento de "cristianização" em Santa Catarina foi ambíguo e a vitória de Vargas foi menos impactante do que se supôs. O intrincado jogo político nacional, suas repercussões locais e as incongruências entre as estratégias de campanha e os resultados das urnas em 1950 são alguns dos elementos que esse artigo se propõe a analisar.
\end{abstract}

Palavras-chave: Eleições. Vargas, Getúlio, 1882-1954. Partidos políticos.

\section{Not as 'Christianised' as it seems: notes on elections in 1950 in Santa Catarina and the victory of Getúlio Vargas}

\begin{abstract}
The victory of the election in 1950, five years after the end of the "Estado Novo" brought Getúlio Vargas back to the command of national executive. In one process of election involved in polemics, the national political chess marked the local political disputes. PTB, PSD, and UDN pragmatically searched for regional alliances and tried to offer good political bases to their presidential candidates in every state. After the announcement of the results of the polls informing the victory of the labour party leader, renowned politicians and journalists manifested their unconformity, blaming PSD for the return of the 'ex-dictator'. The small number of votes that Cristiano Machado, the PSD party candidate, received would be motivated by the disloyalty of that party which had abandoned its official candidacy in favour of Vargas. "Christianity" was the name given to this movement. Santa Catarina, at first, would be one of such cases, in which the local PSD party shifted its support in favour of the labour candidate. However, when observing regional political links and alliances, campaign strategies and the voting in the state discriminating city by city, it is possible to observe that the movement of 'Christianity' in Santa Catarina was ambiguous and that the victory of Vargas was less impacting than it has been supposed. The intricate national political game, its local repercussion, and the incongruencies between campaign strategies and the voting result in the year of 1950 are some elements this paper aims to analyse.
\end{abstract}

Keywords: Elections. Vargas, Getúlio. 1882-1954. Political parties. 
Nem tão "cristianizado" assim: apontamentos sobre as eleições de 1950 em Santa Catarina e a vitória de Getúlio Vargas

Camilo Buss Araujo

Prólogo: A aliança entre UDN e PTB em Santa Catarina e as eleições de $1950^{1}$

O diretório estadual do Partido Trabalhista Brasileiro (PTB) recebeu uma carta da União Democrática Nacional (UDN) de Santa Catarina no dia 1o de setembro de 1950. Na mensagem, o presidente em exercício informava que a UDN não apresentaria candidato ao Senado, apoiando o nome do trabalhista Carlos Gomes de Oliveira. No mesmo dia, a executiva petebista decidiu fazer uma reunião extraordinária e, "penhorados por este alto gesto da UDN e dos demais partidos coligados", respondeu àquela "demonstração de simpatia com uma atitude de idêntica cordialidade." No ofício, o PTB oficializava o apoio a Irineu Bornhausen (UDN) para o governo do estado e abria espaço no cargo de suplente ao Senado para um nome indicado pelos udenistas e demais partidos coligados (O PTB votará..., 1950). Formava-se a aliança que uniria alguns dos principais partidos de Santa Catarina em torno do candidato udenista ao governo, em um ano em que haveria também eleições para a Presidência da República, o Senado, a Câmara Federal, a Assembleia Legislativa, a Prefeitura e a Câmara de vereadores.

A aliança polêmica entre udenistas e trabalhistas em Santa Catarina gerou divergências internas tanto dentro do PTB quanto do Partido Social Democrático (PSD). O PSD catarinense buscava o apoio da legenda trabalhista para manter-se no controle do executivo estadual e para reeleger Nereu Ramos, o principal político do estado, ao Senado. ${ }^{2}$ Já o partido de Vargas cortejava o PSD nos estados, buscando ampliar o leque de apoios à candidatura presidencial. O resultado das eleições de 1950 é conhecido. Getúlio Vargas foi reconduzido à presidência da República e Cristiano Machado, candidato do PSD, teve um desempenho aquém do que se esperava. Para os analistas da época, houve infidelidade de líderes pessedistas, que abandonaram seu candidato majoritário para apoiar Vargas. A esse movimento deu-se o nome de "cristianização".

\footnotetext{
"Este artigo resulta da minha tese de doutorado em História Social, intitulada "Marmiteiros, agitadores e subversivos: política e participação popular em Florianópolis, 1945-1964” defendida em 2013 na Universidade Estadual de Campinas (UNICAMP), sob orientação do professor Dr. Fernando Teixeira da Silva, com bolsa da Fundação de Amparo à Pesquisa do Estado de São Paulo (FAPESP).

${ }^{2}$ Nereu Ramos foi eleito governador do estado em 1935 e interventor federal em Santa Catarina durante o Estado Novo (1937-1945). Era um dos líderes do PSD nacional e o principal político do estado (ARAUJO, 2013, p. 33-38).
} 
Para identificar a infidelidade pessedista, bons estudos analisaram os resultados eleitorais do pleito, comparando o desempenho do PSD nas disputas estaduais e o percentual de votação de seu candidato presidencial. No entanto, a análise exclusiva dos números gerais pode obscurecer as dissonâncias e tensões entre a disputa nacional e as questões regionais. Neste artigo, proponho analisar a eleição de Vargas e o fenômeno da "cristianização" em Santa Catarina a partir de três eixos: 1. Investigar os bastidores das articulações nacionais e locais, observando eventuais incongruências e estratégias de campanha; 2. Analisar os números dos candidatos em Santa Catarina, inclusive a votação por município, e comparar com os resultados em outros estados e no Brasil; 3. Cruzar as informações dos dados eleitorais com os discursos e expectativas de campanha, de modo a matizar melhor a "cristianização" do candidato do PSD no estado.

Algumas hipóteses foram lançadas para se compreender a vitória de Vargas. A primeira delas é que o presidente eleito já teria forte apelo junto às classes trabalhadoras urbanas e, com a "cristianização" do candidato pessedista, sua candidatura ganhou pujança também em áreas menos urbanizadas. Em um município como Florianópolis, capital de Santa Catarina e composta por áreas urbanas e rurais relativamente bem definidas, seria possível testar essa hipótese analisando a distribuição dos votos por seção eleitoral - visto que seria possível mapear geograficamente as forças de cada candidato. No entanto, as fontes disponíveis sobre as eleições de 1950 em Santa Catarina são escassas. Nesse caso, O TRE-SC disponibiliza os resultados por município, mas não por seção eleitoral. Também não foram encontrados documentos dos partidos relacionados ao pleito, como denúncias contra adversários ou tentativas de impugnação de candidaturas. Contudo, informações desse tipo aparecem em outras fontes.

Os três principais jornais de Florianópolis adotavam linhas políticas claras. Em 1950, os jornais O Estado e A Gazeta eram declaradamente pessedistas. O primeiro tinha como dono o governador eleito em 1947, Aderbal Ramos da Silva (PSD), sobrinho de Nereu Ramos, líder maior do partido no estado. O segundo era de propriedade de Jairo Callado, vereador eleito pelo PSD nas eleições de 
novembro de 1947. O Diário da Tarde era de propriedade de Adolfo Konder, principal líder da UDN em Santa Catarina e sogro de Irineu Bornhausen, candidato ao governo do estado em 1950. Ao analisar as fontes jornalísticas, percebe-se, portanto, que os periódicos da capital do estado expressavam, sem pruridos, a opinião dos dois maiores partidos de Santa Catarina, permitindo uma compreensão das estratégias de cada sigla naquele pleito.

A ideia central deste artigo, portanto, passa por cruzar os dados pesquisados sobre as pesquisas de opinião, os resultados eleitorais de 1950 e as informações sobre as tensões e as estratégias políticas dos partidos noticiadas na imprensa. A partir da análise dessas fontes, buscarei testar a validade do conceito de "cristianização" do candidato do PSD em Santa Catarina e compreender melhor as dinâmicas eleitorais no plano estadual e nacional. Em outras palavras, verificar se, de fato, os principais líderes do PSD no estado de Santa Catarina abandonaram a candidatura de Cristino Machado em favor de Vargas. Em caso afirmativo, verificar em que medida isso ocorreu e o impacto eleitoral dessa medida nas diversas regiões do estado.

A eleição de 1950 é sintomática porque traz novamente aos holofotes a figura de Getúlio Vargas. Além de ter exercido a presidência da República entre 1930 e 1945, o político gaúcho era popular entre os trabalhadores urbanos e conhecido por muitos como "pai dos pobres". A centralidade do ex-presidente no pleito dava-se por dois fatores: 1. Trazia novamente para o debate político seu primeiro governo, sobretudo a ditadura do Estado Novo, e reacendia o ressentimento dos seus opositores; 2. Em função de sua aproximação com as classes trabalhadoras, forçava a inserção das pautas populares na disputa eleitoral.

Nesse sentido, os trabalhadores não eram apenas expectadores de um jogo político-partidário feito "por cima". A incerteza das urnas fazia com que pautas trabalhistas fossem colocadas no cenário político, independentemente das ideologias partidárias. Ou seja, o processo eleitoral forçou muitas vezes o diálogo entre grupos políticos e trabalhadores, permitindo a negociação de demandas urbanas e tensionando pela ampliação de direitos. 
Nem tão "cristianizado" assim: apontamentos sobre as eleições de 1950 em Santa Catarina e a vitória de Getúlio Vargas

Camilo Buss Araujo

\section{Articulações nacionais e disputas locais: as expectativas para o pleito de 1950}

A união entre UDN e PTB, urdida pelos diretórios estaduais, contrariava o xadrez político nacional, cujas peças movimentavam-se em torno de alianças visando à eleição presidencial. O acordo interpartidário (PSD-UDN-PR), que oferecera uma confortável maioria no Congresso ao governo Dutra (1946-1950), fracassara em seu objetivo de garantir um candidato consensual para a sucessão em 1950. PSD, UDN e PTB lançavam candidatos próprios à presidência e a viabilidade destas candidaturas dependeria de boas alianças regionais.

A fragilidade do acordo era evidente, principalmente pela dificuldade de se encontrar um candidato de "coalizão nacional". O ano de 1949 foi marcado por tratativas e sugestões de nomes. Todavia, a unidade da base de apoio do governo Dutra para eleição de 1950 esbarrava nas exigências das siglas em encabeçar a candidatura presidencial. Nomes como Nereu Ramos, vice-presidente da República e presidente do PSD, Octávio Mangabeira, da UDN, foram ventilados, mas sem sucesso. Os udenistas ainda tentaram viabilizar uma candidatura que atraísse o PSD não getulista. Juraci Magalhães articulou sem sucesso a candidatura do Ministro da Guerra, o General Canrobert Pereira da Costa. No entanto, pesquisas de intenção de voto nas cidades de São Paulo e Rio de Janeiro apontavam o fraco desempenho do militar. ${ }^{3}$

Em abril de 1950, o PSD rejeitou uma candidatura extrapartidária e em meados de maio definiu Cristiano Machado, deputado federal por Minas, como seu candidato ao Catete - decisão homologada na convenção nacional realizada em junho. A UDN, não sem ressalvas, homologou o nome do Brigadeiro Eduardo Gomes. ${ }^{4}$ Diferentemente de 1945, quando a candidatura do Brigadeiro surgia "naturalmente" como oposição ao regime estadonovista, alguns udenistas demonstravam receio com a indicação.

\footnotetext{
${ }^{3}$ O General Canrobert Pereira da Costa tinha no Rio de Janeiro 0,9\% das intenções de voto. Já em São Paulo contava com 0,3\% das intenções dos paulistanos (INSTITUTO BRASILEIRO DE OPINIÃO PÚBLICA E ESTATÍSTICA, 1949, p. 525).

${ }^{4}$ Segundo Benevides, a Comissão Executiva aprovou a candidatura do Brigadeiro em 28 de abril. Em 12 de maio, a candidatura foi lançada na Convenção Nacional, mas sua homologação se deu na Convenção Extraordinária de agosto (BENEVIDES, 1981, p. 79). Para Sérgio Lamarão, a homologação da candidatura já acontecera em maio (LAMARÃO. [20--])
} 
O acordo interpartidário, construído com objetivo de neutralizar a máquina getulista e oferecer uma perspectiva de coalizão em 1950, desmanchou-se nas divergências políticas entre caciques partidários. A UDN apostava novamente na candidatura do brigadeiro. O fim da aliança com o PSD, a "mão direita de Vargas", revelou parte da ambiguidade política e das incoerências internas do partido. Para Benevides, a indefinição política dos udenistas, ao oscilarem entre o radical antigetulismo e o realismo conciliatório, os fez perder o carisma de 1945. Carisma este que não foi substituído pelo pragmatismo político necessário para enfrentar a eficiente campanha de seu maior inimigo. Na perspectiva udenista, a aliança interpartidária fora "feita com remorso e desfeita com frustração." (BENEVIDES, 1981, p. 223).

Getúlio Vargas, por sua vez, articulou sua candidatura nas estâncias de sua família, em São Borja. Durante o governo Dutra, teve uma atuação parlamentar discreta e na maior parte das vezes, ausente. ${ }^{5}$ Contudo, o ex-presidente não se afastou da vida política. De sua terra natal, traçava estratégias para expansão eleitoral do PTB e procurava pavimentar o caminho de seu retorno ao Catete. Nas eleições de 1947, percorreu diversos estados brasileiros fazendo campanha. Em São Paulo, apoiou para vice-governador o nome de Cirillo Júnior, do PSD, um político de oposição, contra Noveli Júnior, apoiado pelo governador Adhemar de Barros. Na queda de braço entre Getúlio e Adhemar, venceu o político paulista que conseguiu emplacar seu candidato na vice-governança do estado.

A partir dos resultados de 1947, o ex-presidente inicia seus diálogos com o governador paulista, tendo em vista uma possível aliança no pleito presidencial vindouro. Para o PTB, o peso político de São Paulo representava um trunfo para vencer as resistências militares contra vargas e um ponto fundamental para reverter a desvantagem em relação à máquina pessedista. Era preciso, portanto, demover o governador paulista de sua intenção de disputar a eleição presidencial.

\footnotetext{
${ }^{5}$ A legislação eleitoral da época permitia candidatar-se para mais de um cargo e por mais de um estado. Desse modo, Vargas elegeu-se senador pelo PSD do Rio Grande do Sul e pelo PTB paulista. Elegeu-se também deputado federal pelos mesmos estados: Distrito Federal, Minas Gerais, Rio de Janeiro, Bahia e Paraná (MOREIRA, [20--]).
} 
O PSP contava, por seu turno, com uma influente rede política no estado mais industrializado do país, construída desde a intervenção de Adhemar de Barros. Esta rede era tecida por subdiretórios distritais, por bairro, por área industrial ou residencial, conectados a um diretório municipal. Os diretórios distritais indicavam o juiz de paz, o delegado de polícia e o subdelegado. Cada subdelegado escolhia os inspetores de quarteirão. Desse modo, o PSP adhemarista estabelecia uma grande rede de influência que o aproximava das classes trabalhadoras paulistas. ${ }^{6}$ Todavia, a candidatura do governador paulista não tinha a mesma capilaridade no restante do país. Para viabilizá-la, eram necessários investimentos e alianças nos demais estados da federação. Além disso, um eventual fracasso eleitoral poderia representar a perda da poderosa máquina administrativa e política construída.

A aliança entre PTB e PSP tornou-se pública em maio de 1950. Em retribuição, os pessepistas indicaram o vice, João Café Filho. Os trabalhistas não se restringiram, no entanto, às alianças formais. Estabeleceram um acordo velado com parte do PSD, bem como procuraram alianças com os mais diferentes partidos nos estados. De acordo com Lucília de Almeida Neves Delgado, Vargas procurou todos os partidos. Em Minas Gerais, o PTB apoiou o pessedista Juscelino Kubitschek. Em Pernambuco, defendeu a candidatura de João Cleofas, da UDN (DELGADO, 2011, p. 88). O PTB adotava, portanto, o pragmatismo político como estratégia para fortalecer a candidatura de Vargas. Com isto, dividiu o PSD que, em parte, abandonou a candidatura de Cristiano Machado.

Nesta perspectiva, tendo em vista que o PTB negociava indiscriminadamente o apoio dos partidos nos estados, a aliança entre udenistas e trabalhistas em Santa Catarina não aparece como um movimento destoante no xadrez político daquelas eleições. Entretanto, as circunstâncias em que a coligação foi construída e seus desdobramentos demonstram brigas intestinas no PTB local, bem como episódios de desobediência na relação entre o comando nacional e o diretório estadual.

\footnotetext{
${ }^{6}$ No bairro da Mooca havia, por exemplo, dois diretórios distritais do PSP. Cada um contava com 25 subdelegados os quais, por sua vez, coordenavam entre cinco e dez inspetores de quarteirão. Segundo Duarte, sem muito esforço, cada diretório atendia cerca de 250 ruas, conectando todo bairro à rede pessepista (DUARTE, 2002, p. 161; SAMPAIO, 1982, p. 135-139).
} 
As cisões no PSD facilitaram as articulações regionais em torno da candidatura Vargas. As seções estaduais fiéis a Nereu Ramos não apoiaram o candidato oficial, ressentidas com a indicação de Cristiano Machado, considerada uma medida arbitrária do presidente Dutra. De acordo com Maria Celina D’Araújo, a chamada "cristianização", ou seja, o abandono da candidatura de Cristiano Machado em favor de Getúlio Vargas, era quase obrigatória para amplos setores pessedistas que não poderiam, em nome da lealdade partidária, aumentar os riscos de derrotas eleitorais (D’ARAUJO, 1992, p. 71). No Rio Grande do Sul, as alas dutrista e getulista do PSD cindiram definitivamente pouco antes do anúncio da candidatura de Cristiano Machado, em meados de maio. João Neves da Fontoura, um dos líderes da dissidência getulista no PSD gaúcho, em carta ao expresidente, afirmava que, com a exclusão de Nereu Ramos, apoiaria o candidato indicado por Vargas (OLIVEIRA, 2008, p. 210). As divergências no seio da seção regional fizeram também com que fossem lançados dois candidatos ao governo do estado: Cylon Rosa, pelo grupo dutrista, e Ernesto Dornelles, pelos getulistas. ${ }^{7}$ Em agosto, a convite de Vargas, o pessedista Ernesto Dornelles aceitou ser candidato ao governo do estado pelo PTB, contando, evidentemente, com o apoio do PSDA.

Pela lógica das articulações políticas, a tendência seria que, em Santa Catarina, o PTB apoiasse o nome pessedista ao governo do estado. Em troca, o partido de Nereu Ramos tornaria oficial o seu apoio ao ex-presidente, abandonando a candidatura de Cristiano Machado. As deliberações do PTB estadual contrariaram tanto as perspectivas do comando nacional, dedicado a arquitetar a candidatura de Vargas, quanto as pretensões do PSD local, cujo objetivo era formar uma coligação forte e garantir-se no controle do executivo estadual por mais quatro anos. A troca de "gentilezas" entre líderes udenistas e trabalhistas de Santa Catarina indicava que as articulações nacionais nem sempre se sobrepunham às dinâmicas políticas locais. Ademais, foi um duro golpe nas pretensões do PSD catarinense. Afinal, após ver seu principal quadro preterido na questão sucessória pelo presidente Dutra, não havia qualquer

\footnotetext{
A dissidência getulista do PSD foi batizada de PSD Autonomista (PSDA), comandada por Francisco Brochado da Rocha, Glicério Alves e Ernesto Dornelles. No fim de junho de 1950, João Neves da Fontoura, um dos líderes do grupo, aceitou ser o presidente do Comitê Nacional da campanha de Vargas, tornando-se responsável por escrever alguns dos discursos do candidato. (OLIVEIRA, 2008, p. 210).
} 
inclinação em apoiar o candidato oficial. Além disso, o apoio do PTB, principalmente na figura de Vargas, era fundamental para fortalecer a candidatura do pessedista Udo Deeke ao governo do estado.

Para os pessedistas catarinenses, a aliança com os trabalhistas seria, sobretudo naquelas circunstâncias, a situação política ideal. Vargas para presidente, Udo Deeke para governador e Nereu Ramos para senador. No lado petebista, cujo objetivo maior era estruturar e solidificar o apoio à candidatura de Vargas, uma aliança PSD-PTB em Santa Catarina era algo bem visto. Entretanto, a troca de telegramas e a formalização da aliança UDN-PTB para as eleições estaduais desestabilizaram as articulações políticas tanto do comando nacional trabalhista quanto do diretório regional pessedista. Resignar-se não era uma opção. Os periódicos pessedistas denunciaram a ilegalidade do ato e, dias depois, comemoraram a intervenção do diretório nacional na seção catarinense do PTB.

\section{Pesquisas de opinião e as escolhas do PTB}

Meses antes do acordo, o jornal $A$ Gazeta publicara, em primeira página, manchete negando que o PTB teria feito aliança com a UDN em Santa Catarina. A reportagem trazia uma entrevista com Saulo Ramos na qual o político negava a coligação: "Como trabalhista, desejo que o PTB tenha candidatos próprios para todos os cargos eletivos estaduais e federais."(NÃO é..., 1950). E, de fato, o partido caminhava para a candidatura própria, com Carlos Gomes de Oliveira para o governo do estado. Entretanto, nos bastidores, UDN e PSD negociavam o apoio dos trabalhistas. A despeito de, nos pleitos anteriores, não ter feito uma votação expressiva em Santa Catarina, o PTB possuía, naquela eleição, um forte catalisador de votos: Getúlio Vargas.

Já não era mais novidade que as campanhas com mais chances de sucesso eram aquelas com apelo popular. Era justamente nesta seara que residia o prestígio do ex-ditador, como as próprias pesquisas de opinião anteriores ao pleito apontavam. Na pesquisa de intenção de voto realizada pelo IBOPE no Rio de Janeiro e em São Paulo, em 1949, Vargas aparecia em primeiro, com 34,4\% e 40,3\%, respectivamente, contra 32,2\% e 24\% de Eduardo Gomes. Na distribuição 
por classe social, em São Paulo, o Brigadeiro vencia nas classes A e B - definidas na pesquisa como "Rica" e "Média" - com 33,4\% e 39,6, respectivamente, contra $16,7 \%$ e $24,6 \%$ do ex-presidente. No entanto, na classe C, definida na pesquisa como "Pobre", Vargas auferia 55,8\% da preferência do eleitorado, contra apenas 9,8\% de Eduardo Gomes. É importante ressaltar que nesta pesquisa ainda aparecia o nome de Adhemar de Barros como candidato a presidente. 0 governador paulista obteve 9,4\% das intenções de voto entre os paulistas, sendo 9\% e 10,4\% nas classes B e C. Na classe A, o governador do estado não obteve votação (INSTITUTO BRASILEIRO DE OPINIÃO PÚBLICA E ESTATÍSTICA, 1949, p.525). Os números da pesquisa em São Paulo emitiam dois principais recados. Primeiro, a despeito do percentual significativo obtido pelo Brigadeiro, deixando claro que sua candidatura não nascera fracassada, como apontaram alguns analistas em estudos posteriores, a eleição mais uma vez seria decidida pelo voto dos trabalhadores. Segundo, se São Paulo, por ser o maior colégio eleitoral do país, poderia ser decisivo no resultado daquela eleição, o apoio do governador Adhemar Barros seria um trunfo fundamental para as aspirações de qualquer uma das duas candidaturas. Para Vargas, a aliança significaria a consolidação de uma quase unanimidade entre os trabalhadores. Para o Brigadeiro, o apoio do governador paulista seria um meio de conseguir algum respaldo popular e romper com o estigma de candidato das elites.

No Rio de Janeiro, a diferença de intenção de voto entre os dois candidatos foi de 2,2\%. Não há menção ao que hoje se conhece como "margem de erro", mas é evidente que, mesmo para os padrões atuais, essa pequena diferença indicava um empate técnico na capital da República. Entre as classes A e B, Eduardo Gomes vencia com 40\% e 47,8\%, respectivamente, contra 28\% e 26,9\% de Getúlio Vargas. Na classe C, a pesquisa apontava a vantagem de Vargas, com 42,5\%, contra 23,1\% do Brigadeiro. Isto é, a pequena vantagem do ex-presidente era conquistada com os votos da classe operária. Em terceiro lugar na pesquisa aparecia o nome de Oswaldo Aranha, com 7,1\% da preferência dos entrevistados, seguido por Adhemar de Barros, com 4\%.8

\footnotetext{
Por ser uma pesquisa realizada no ano de 1949, período quando ainda se articulavam as candidaturas, não aparece entre os nomes de possíveis candidatos o pessedista Cristiano Machado.
} 
Em agosto de 1950, portanto, após as definições da aliança entre Adhemar de Barros e Getúlio Vargas e da homologação de Cristiano Machado como candidato do PSD, nova pesquisa realizada na capital federal apontava o expresidente com 38,4\% das intenções de voto, contra 28,8\% de Eduardo Gomes, 9,3\% de Cristiano Machado e 0,5\% de João Mangabeira. Apesar de não discriminar a porcentagem de cada candidato por classe social, como feito na pesquisa do ano anterior, o levantamento do IBOPE procurou saber a opinião dos entrevistados sobre as virtudes e os defeitos dos presidenciáveis. Entre os getulistas, as principais vantagens apontadas pelos entrevistados eram ser "um grande chefe da classe trabalhadora" e um "bom administrador". Entre os brigadeiristas, o principal atributo era "sua grande honestidade". Já os eleitores de Cristiano Machado destacavam sua "dignidade e honestidade". Ao questionar sobre os defeitos que pesavam contra Vargas, os entrevistados assinalavam a pecha de "ditador" e "antidemocrático". Contra Eduardo Gomes, "ser militar" e "só servir a elite". Contra Cristiano Machado, os principais problemas eram ser uma figura desconhecida e ser "O candidato de Dutra" (INSTITUTO BRASILEIRO DE OPINIÃO PÚBLICA E ESTATÍSTICA, 1950b, p. 189).

As duas pesquisas de intenção de voto realizadas no Rio de Janeiro no intervalo de pouco mais de um ano revelam o crescimento da vantagem de Vargas sobre Eduardo Gomes. No interregno entre os levantamentos, aconteceu a definição de Vargas como candidato à presidência, as disputas internas e as decorrentes cisões dentro do PSD e a definição da candidatura de Cristiano Machado - político que sequer aparecia na pesquisa de 1949. Demonstrava-se bem sucedida a estratégia da candidatura de Vargas de fortalecer sua imagem de candidato popular. Enquanto o candidato udenista, em que pese o reconhecimento público de sua honestidade, não conseguia ampliar sua base eleitoral. O estigma de ser um candidato das elites o prejudicava. No PSD, as interferências de Dutra nas disputas internas do partido e a escolha de um candidato pouco conhecido do grande público - como a pesquisa a menos de dois meses para o pleito apontara - permitiram a infidelidade de alguns caciques pessedistas que optaram por apoiar a candidatura trabalhista de Vargas. 
Em setembro, o IBOPE ouviu 600 eleitores de São Paulo. Os números da capital paulista mostravam vantagem significativa de Vargas a pouco menos de um mês para a eleição, com 67,2\% da preferência dos entrevistados. Eduardo Gomes, Cristiano Machado e João Mangabeira ficavam com 21,7\%, 2\% e 0,8\%, respectivamente. Todavia, a distribuição socioeconômica dos votos indicava a vitória do Brigadeiro entre a classe rica (66,6\% contra 16,7\% de Vargas), equilíbrio entre a classe média (48,7\% de Vargas contra 37\% de Eduardo Gomes) e vantagem expressiva de Vargas junto aqueles tidos como "pobres" pela pesquisa (83,2\%, contra 8,1\% do Brigadeiro) (INSTITUTO BRASILEIRO DE OPINIÃO PÚBLICA E ESTATÍSTICA, 1950a, p. 208). Mais uma vez os números mostravam que a vantagem da candidatura trabalhista assentava-se justamente onde a candidatura udenista não conseguia chegar: nas classes trabalhadoras. Não é por acaso que Carlos Lacerda, em seu recém-criado Tribuna da Imprensa, alertava que a vitória de Vargas significaria "a divisão do Brasil em duas partes: a parte dos que aclamariam a volta da traição, até que se desenganassem tardiamente, e a parte, também numerosa, dos que não se conformariam com essa situação - e iriam às armas, e impediriam PELAS ARMAS se necessário, a volta do Sr. Getúlio Vargas ao poder." (MENDONÇA, 2002, p. 115). O jornalista sinalizava, assim, a tônica das relações entre governo e oposição caso, através do voto direto, o "pai dos pobres" fosse alçado novamente ao Catete. Na iminência do processo eleitoral, que decidiria os cargos executivos de todo o país, mostrava-se fundamental construir uma imagem positiva junto às classes trabalhadoras. Consequentemente, vincular-se ao nome de Vargas poderia ser decisivo.

No final de julho de 1950, o Diário da Tarde criticava a visita do "queremista" Francisco Brochado da Rocha em Santa Catarina com intuito de articular uma aliança PTB-PSD. ${ }^{9}$ Os "nereusistas" apoiariam Getúlio Vargas para presidente e os trabalhistas apoiariam Udo Deeke para o governo do estado. Caso concretizada a negociação, afirmava o periódico udenista, a candidatura de Carlos Gomes de Oliveira ao governo do estado seria apenas uma manobra política, com objetivo de "abrandar a antipatia dos trabalhistas catarinenses contra o atual desgoverno." (DIÁRIO DA TARDE, 1950).

\footnotetext{
9 O termo "queremista" era usado pelo Diário de Notícias para designar a ala getulista do PSD gaúcho, o PSDA, do qual Francisco Brochado da Rocha fazia parte. (OLIVEIRA, 2008, p. 221).
} 
Menos de um mês depois, o PSD catarinense vibrou quando Carlos Gomes de Oliveira retirou sua candidatura ao governo do estado. Em carta aberta, o político trabalhista afirmou que a construção de sua candidatura se deu por aclamação do partido, ciente que poderia ser uma oportunidade para, se não uma "vitória final", um "êxito relativo nas urnas". Contudo, informava o excandidato ao governo, após ponderar as vantagens e desvantagens da manutenção da candidatura junto ao Diretório Estadual e com o delegado do Diretório Nacional do PTB, Manoel Vargas, concluía que seria melhor retirá-la. Isso porque o PTB tinha uma bandeira naquela eleição: Getúlio Vargas. Portanto, os acordos, "se não puderam ser feitos como desejamos, dentro de uma fórmula alta, de conciliação entre os partidos, também não poderiam abstrair das cogitações que são principais entre os trabalhistas, de uma maior votação para Getúlio Vargas.” (PTB, 1950).

A retirada da candidatura de Carlos Gomes a pouco mais de um mês para o pleito indicava que o PTB pretendia fazer alianças em Santa Catarina. O excandidato lamentava não ter a oportunidade de se candidatar, afinal, era o desejo de algumas lideranças regionais do partido. Contudo, o relato deixa subentendido que a decisão foi tomada após conversas com membros do PTB estadual, afinados com o comando nacional - o Diretório Estadual e o delegado do Diretório Nacional. Ou seja, mesmo transparecendo uma aparente harmonia, a retirada da candidatura própria não era uma unanimidade no partido. O próprio ex-candidato deixava claro sua contrariedade visto que os acordos interpartidários não foram feitos da forma como os trabalhistas desejavam talvez denotando certa mágoa por seu tradicional aliado, o PSD, não abrir nenhum espaço para os trabalhistas na chapa majoritária. No entanto, para garantir uma maior votação a Vargas, era preciso coligar-se, mesmo que não fosse nas bases desejadas pelo partido.

Ora, a coligação lógica que traria uma "maior votação para Getúlio Vargas" era com o PSD, visto que a UDN catarinense não teria razões para abandonar o nome do Brigadeiro - diferente do partido de Nereu Ramos em relação a Cristiano Machado. Parece claro, portanto, que a retirada da candidatura estava vinculada a pressões do Diretório Nacional e que o indicativo seria o apoio do 
PTB ao pessedista Udo Deeke para o governo do estado e a Nereu Ramos para o Senado. Em troca, o PSD catarinense ignoraria a candidatura oficial do partido, aderindo à campanha de Getúlio Vargas. Considerando o histórico de divergências partidárias que solaparam o nome do líder catarinense e alçaram Cristiano Machado como candidato ao cargo máximo da nação, a infidelidade dar-se-ia sem remorso algum.

\section{Uma campanha de apelo ao trabalhador: UDN e PSD lançam} candidatos ao governo de olho no prestígio político de Vargas

Enquanto o PTB decidia sobre a candidatura própria, os pessedistas faziam campanha junto aos trabalhadores. Para as eleições de 1950, o PSD catarinense fechou sua chapa com antecedência. O nome do engenheiro blumenauense e ex-interventor Udo Deeke foi lançado na convenção do partido de 27 de junho. Em primeira página, O Estado dirigia-se ao operário pleiteando votos para o candidato do PSD ao governo do estado, "para consolidar os teus direitos e para assegurar-te (...) o conforto de que és merecedor". Finalizava dizendo: “Udo Deeke, engenheiro, é como tu, um trabalhador, e, como tu, deseja o progresso de Santa Catarina." (OPERÁRIO, 1950. Grifo nosso). Ficava claro que a seção catarinense buscaria uma aproximação com a figura de Vargas através daquilo que mais tocava na classe trabalhadora, a legislação trabalhista. No entanto, teria de disputar o eleitorado com os udenistas catarinenses.

Bem diferente da pauta anticomunista das eleições municipais de novembro de 1947, a UDN partia em direção ao operariado. Nas acusações dos oposicionistas, os trabalhadores catarinenses não gozavam dos benefícios da legislação trabalhista porque o PSD fizera manobras na Constituição Estadual. E alertava: "não te esqueças de que o governo tratou teus companheiros com gases lacrimogêneos, quando eles buscaram melhorias para sua vida." (OPERÁRIO, 1950). O periódico pessedista respondia relembrando o papel oposicionista da UDN contra Getúlio Vargas. Admirava-se com o cortejo ao "eleitorado getulista para obter-lhe o apoio do voto" uma vez que os udenistas queriam “a todo custo extinguir o trabalhismo". Enquanto o PSD, afirmava o jornal, lutava pelas "conquistas do trabalhador nacional, a bancada udenista tudo 
fazia, ostensiva ou sigilosamente, para impedir que se codificassem os direitos sociais do homem de trabalho". Portanto, concluía, se "devem ao Sr. Getúlio Vargas a legislação de que se beneficiam ainda hoje os operários nacionais, não menos justo é que creditem ao partido majoritário, ou seja ao PSD e aos seus representantes, a manutenção daquelas conquistas até o presente." (ESSES..., 1950)

Percebe-se, por conseguinte, que Vargas era a figura central daquela eleição. O pleito nacional girava em torno do apoio/oposição à sua figura. Na eleição para o governo de Santa Catarina, disputava-se quem seria o melhor mantenedor dos direitos trabalhistas. Nos periódicos dos dois principais partidos, não há ataques à figura do ex-presidente. De um lado os oposicionistas cortejavam o trabalhador, acusando o PSD de não implementar a legislação trabalhista durante os anos em que esteve no poder. De outro, os pessedistas respondiam se autointitulando mantenedores das conquistas sociais adquiridas durante o governo Vargas. Em meio ao fogo cruzado permanecia o PTB, sem saber se optava pela candidatura própria ou buscava alianças. O "partido de Vargas" realmente poderia ser decisivo nas eleições estaduais - mais pelo vínculo com a figura do ex-presidente do que pela estrutura partidária ou pelo desempenho em eleições anteriores. Talvez por isso, ir a reboque do PSD novamente para o governo e para o senado ficava aquém das suas expectativas, visto que teria como grande arma eleitoral o seu nome maior.

Após a troca de cartas que tornou públicas as articulações entre udenistas e trabalhistas, o PSD dedicou-se a denunciar a ilegalidade do ato. Nas semanas seguintes, acusações mútuas e informações contraditórias ocuparam espaços de destaque nos jornais de situação e oposição. O Estado, periódico vinculado ao PSD, trazia um trecho da entrevista de Adolfo Konder, líder da UDN em Santa Catarina, ao jornal 0 Globo em que afirmava que o partido não abandonaria a candidatura de Eduardo Gomes e avisava: "a recomendação dos trabalhistas de apoiarem a candidatura de Irineu Bornhausen não favorecerá a candidatura de Getúlio Vargas como propalam alguns dirigentes do PTB." (O ESTADO, 1950a). Dias depois, $A$ Gazeta, também vinculada ao PSD, publicava uma entrevista de Danton Coelho, presidente nacional do PTB. A matéria reiterava que o acordo feito em 
Santa Catarina não obtivera a autorização do comando nacional e pedia para que os líderes catarinenses, Saulo Ramos e Carlos Gomes de Oliveira, o desfizesse (SENSACIONAL, 1950). No dia seguinte, o jornal publicava a união entre PSD e PTB para a eleição municipal de Joinville. O candidato pessedista, Ademar Garcia, retirara a candidatura em favor do petebista Rodrigo Lobo (O PTB..., 1950).

Por sua vez, o Diário da tarde, principal periódico de oposição, comemorou a união dos principais partidos de Santa Catarina em torno da candidatura de Irineu Bornhausen. UDN, PTB, PRP, PSP, PDC e PL estavam juntos contra o "PSD cabisbaixo e triste do senhor Nereu Ramos." (COM IRINEU..., 1950). Dias depois, em face das pressões internas e externas para que o acordo UDN-PTB fosse rompido, o jornal transcreveu uma carta do candidato ao senador Carlos Gomes de Oliveira. O líder trabalhista deixava claro que, a partir do momento em que se decidiu pela não candidatura própria ao governo do estado, o partido sentia-se livre para apoiar qualquer candidato. Tendo em vista que a UDN ofereceu apoio à sua candidatura, bem como a dos demais partidos coligados, o PTB catarinense decidiu sufragar o nome do candidato udenista. Ressaltava ainda que o candidato da UDN se comprometera em fazer um governo dando a "máxima atenção" às classes trabalhadoras e que só aceitou sua candidatura ao Senado após ouvir “elementos dos mais responsáveis no PTB e junto ao Senador Getúlio Vargas”. Finalizava afirmando: "Sei de correntes contrárias. Isso, porém, não pode alterar a posição que assumimos em face da UDN e seus coligados. O Partido Trabalhista em Santa Catarina é que está fazendo campanha pela candidatura de Vargas em nosso estado. [...] E eu, pessoalmente, tenho compromissos indestrutíveis para com Getúlio Vargas. O mais que for, se acertará no caminho." (FALA-NOS..., 1950.

No entanto, enquanto o candidato do PTB deixava claro que obtivera autorização para lançar candidatura própria ao Senado, os jornais pessedistas pediam documentos comprobatórios da autorização do acordo pelo comando nacional (CADÊ..., 1950. No final da primeira quinzena de setembro, O Estado dedicava parcela significativa de suas edições para denunciar a irregularidade da aliança. ${ }^{10}$

\footnotetext{
10 O jornal O Estado, após ouvir o jornalista Domingos Fernandes de Aquino, integrante do PTB de Florianópolis, informou que não havia documento algum que comprovasse a aprovação, por parte do comando nacional petebista, do acordo supostamente firmado entre a seção catarinense e a UDN. Fonte: (NÃO..., 1950).
} 
A intervenção no diretório catarinense do PTB foi noticiada no dia 14 de setembro de 1950. Em dois telegramas aos líderes trabalhistas, Danton Coelho, presidente do partido, sinalizava que, caso a seção catarinense não retirasse sua candidatura ao Senado em favor do candidato pessedista, o Diretório Nacional do PTB providenciaria "a nomeação de uma comissão para dirigir o pleito composta por elementos notoriamente favoráveis à corrente de Nereu." (A VERDADE..., 1950). Dois dias depois, as seções municipais receberam telegrama circular informando os nomes dos integrantes da nova Comissão Executiva designada para atender às instruções do comando nacional e de Getúlio Vargas. Em outras palavras, "prestigiar neste estado a corrente chefiada pelo senhor Nereu Ramos, ficando, por conseguinte, sem efeito a recomendação de votar no candidato a governador pela UDN.” (TELEGRAMA..., 1950).

Em consonância com os apontamentos de estudos anteriores, o comando nacional do PTB adotava o pragmatismo político para garantir a eleição de seu nome maior (DELGADO, 2011). Mais importante do que aventurar-se numa candidatura ao Senado, era solidificar as bases de apoio a Vargas. Contudo, as articulações esbarravam em disputas regionalizadas, em tensões locais que dificultavam a estruturação da candidatura presidencial. A desobediência da seção catarinense do PTB e a intervenção do comando nacional deram visibilidade a disputas internas que, a partir de então, ficariam cada vez mais latentes.

A ala destituída não se submeteu pacientemente às ordens de Danton Coelho. Apoiada pelo veículo udenista - que tratara o episódio como um golpe contra "cidadãos dignos que não se curvaram às imposições dos intrusos nereusistas.” (INTERVENÇÃO..., 1950) - organizaram um ato público para manifestar "simpatia e solidariedade" à candidatura de Carlos Gomes (GRANDE..., 1950). Em seguida vieram as notas criticando a intervenção e afirmando a legitimidade da coligação UDN-PTB. Em contrapartida, os dois jornais ligados ao PSD ocuparam suas páginas com notícias sobre a suposta ilegalidade da aliança. No entanto, à revelia das intervenções do Diretório Nacional trabalhista, Carlos Gomes de Oliveira manteve-se como o candidato do partido ao Senado. 
Formava-se, assim, um cenário político ambíguo e contraditório. O PSD apostava na dissensão entre os trabalhistas para, conjugado com o apoio a Vargas, alavancar a candidatura de Udo Deeke ao governo e eleger Nereu Ramos ao Senado. O PTB, que rompera a parceria com os pessedistas da eleição anterior, arvorava-se como "o legítimo representante da candidatura de Vargas" enquanto consumia-se em brigas intestinas em torno da coligação estadual. Já a UDN, em razão do acordo com o PTB e da necessidade de aproximação com as classes trabalhadoras, pôs de lado o discurso antigetulista na esperança de galgar ao executivo estadual. Paradoxalmente, fez campanha para o Brigadeiro Eduardo Gomes, um símbolo da oposição a Vargas. No bojo das disputas locais, jazia a candidatura de Cristiano Machado, objeto de discórdias no seio do PSD e abandonada em Santa Catarina pelos principais líderes do partido.

Estava claro que a presença de Vargas tornava a eleição de 1950 diferente das anteriores. Afinal, os três partidos que disputavam a presidência tinham sua "razão de ser" na figura do ex-presidente. PSD e PTB nasceram com a pecha de “mão direita" e "mão esquerda" de Vargas. Por sua vez, a UDN tinha no seu âmago a cruzada contra o Estado Novo. Um partido criado inicialmente para aglutinar uma ampla frente de oposição àquilo que genericamente chamavam de "getulismo".11 Com a entrada de Vargas no processo sucessório de 1950, o pragmatismo e as incongruências das articulações políticas confrontavam-se com as orientações doutrinárias fundamentais de cada uma das três siglas.

\section{Presidenciáveis visitam Santa Catarina e Cristiano Machado é recebido com peru com farofa e bife com ervilhas pelo PSD}

O periódico O Estado, do PSD, publicou no dia 12 de setembro a chapa do partido para aquelas eleições, com destaque de capa. Encabeçava a lista o nome de Udo Deeke, engenheiro civil, para governador, seguido de Nereu Ramos, advogado, para o Senado, João David Ferreira Lima, advogado, para suplente ao Senado e as listas de candidatos a deputados federais e estaduais com suas

\footnotetext{
Delgado, baseada em análises de Benevides, afirma que Vargas criou simultaneamente um partido de patrões, um partido de trabalhadores e ainda provocou o surgimento de um terceiro, fundado unicamente para combatê-lo. Para a autora, o PTB era o principal alvo da oposição udenista, uma vez que simbolizava a faceta trabalhista do projeto de vargas. (DELGADO, 2011, p. 32).
} 
respectivas profissões (PARTIDO..., 1950). O que o jornal "esqueceu" de citar foi o nome do candidato oficial do partido: Cristiano Machado. O "descuido" não era casual. Para aquele dia estava marcada a visita do candidato do PSD à capital de Santa Catarina. No entanto, não havia qualquer menção à presença do candidato. A mensagem era clara. A seção catarinense do PSD, comandada por Nereu Ramos, destacava na capa do jornal de seu sobrinho o conjunto de candidatos do partido aos postos eletivos, excluindo o candidato oficial à presidência. Sinalizava-se a "cristianização" do candidato pessedista, ao menos na capital do estado.

No dia seguinte, o mesmo jornal, em pequenas letras no alto da primeira página, noticiava a visita do presidenciável pessedista. Sem comícios ou grandes recepções. Apenas um "concorrido almoço" no Clube 12 de Agosto, cuja presença política mais expressiva era a de José Boabaid, presidente da Assembleia Legislativa (O ESTADO, 1950b). Por sua vez, o jornal ligado à UDN tratou de capitalizar as divergências internas de seus adversários. Em reportagem destacada, detalhou a frieza com que fora recebido o candidato pessedista. Nereu Ramos, justamente quando tentava aproximar-se das hostes trabalhistas e desfazer o acordo entre UDN e PTB, teve de preparar "às pressas" uma recepção a Cristiano Machado.

De acordo com o relato dos oposicionistas, foram pintadas “... duas (DUAS!) faixas com o nome de sua excelência" e pregados "vinte e poucos retratos". Para o presidenciável, nem mesmo um almoço no Palácio do Governo, "coisa que muito figurão de menor importância tem recebido". Apenas "uns bifes à cavalo com ervilhas, um peru com farofa no restaurante do Clube Doze e, enquanto o Sr. Cristiano Machado almoçava, havia um empregado espetando o garfo à parede e virando as vassouras de pernas para o ar para que sua excelência desse o fora quanto antes...". Sem comício, reunião ou contato com o povo, "tão depressa foi servido o cafezinho, meteram o candidato num auto de volta à Base Aérea para ir excursionar pelo Vale do Itajaí". Enquanto abandonava seu candidato, o PSD local encaminhava os "propalados preparativos para a recepção do chefe trabalhista, a quem prometem tudo", com o único objetivo de “aproveitar-se da popularidade do Sr. Getúlio Vargas." (CRISTIANO..., 1950). 
Para a vinda de Vargas, nada de bife com ervilhas ou peru com farofa. 0 periódico pessedista dava destaque em primeira página à chegada do "eminente brasileiro", "a quem Santa Catarina deve grandes e assinalados serviços”. O expresidente, ao contrário do adversário pessedista, seria recebido no aeroporto pelo governador do estado (O ESTADO, 1950c. Na parte inferior da primeira página, o jornal destacava uma nota do Sindicato dos Empregados no Comércio de Florianópolis, pedindo aos empregadores que fechassem os "estabelecimentos comerciais e industriais" naquela tarde. Isso para que os “empregados e operários” pudessem participar da recepção a Getúlio Vargas, "grande amigo dos trabalhadores e autor da nossa benéfica legislação trabalhista e social." (APELO..., 1950).

O periódico da UDN também destacou a vinda de Vargas ao estado. Sem deixar de alfinetar os "nereusistas" do PSD que, ao cortejar o candidato trabalhista, emplacavam uma dupla traição. A primeira com Cristiano Machado, candidato oficial do partido e relegado a segundo plano em sua visita. E a segunda com o próprio Getúlio Vargas, ao lembrar que Nereu Ramos apoiara a insurreição dos paulistas em 1932 contra o seu governo. Mesmo com as críticas, a reportagem destacava o caráter festivo do evento, com a cidade coberta de "cartazes e bandeirolas" e gente "vinda de todas as partes do estado." (A CHEGADA..., 1950).

Getúlio foi recebido em Joinville e desfilou em carro aberto ao lado de Udo Deeke, candidato do PSD ao governo do estado. Em Florianópolis, ladeado por Nereu Ramos, percorreu a cidade "enfeitada de faixas, cartazes e pendões." (GETÚLIO..., 1950). Às 20 horas, após jantar no Palácio do Governo, participou do comício na companhia do governador Aderbal Ramos da Silva. De acordo com os periódicos pessedistas, o presidenciável foi ovacionado por "enorme massa popular de 20 mil pessoas." (DESLUMBRANTE..., 1950).

Todos os três principais jornais da capital de Santa Catarina trataram de ressaltar a mobilização provocada pelo comício daquele que seria o principal líder das classes trabalhadoras e "autor da legislação trabalhista”. No entanto, o discurso do candidato foi objeto de diferentes interpretações. Afinal, a quem Getúlio manifestou seu apoio? Ao correligionário Carlos Gomes de Oliveira, 
Nem tão "cristianizado" assim: apontamentos sobre as eleições de 1950 em Santa Catarina e a vitória de Getúlio Vargas

Camilo Buss Araujo

candidato ao Senado em coligação com a UDN? Ou a Nereu Ramos, líder do PSD, candidato ao Senado e um dos principais responsáveis pela intervenção nacional no diretório estadual do PTB? Parece lógico que os partidos disputassem sua indicação. Afinal, ser reconhecido como o "candidato de Vargas" poderia ser um diferencial fundamental naquele disputado processo eleitoral.

Ao finalizar seu discurso pedindo votos para Udo Deeke, para governador, e Nereu Ramos, para senador, Vargas deixaria claro sua opção pelo pragmatismo político e a prioridade por coligações amplas o bastante para garantir sua eleição. ${ }^{12}$ No entanto, o órgão udenista descreveu um comício repleto de apupos aos "nereusistas" e com clamores aos candidatos "populares", Carlos Gomes e Irineu Bornhausen (A CHEGADA..., 1950, p. xx). A descrição do órgão udenista, repleta de superlativos, deve ser tomada com cautela. Parece claro que o confronto entre o comando nacional petebista e o diretório regional gerou uma forte cisão entre os correligionários locais. É verdade também que tanto a UDN quanto o PSD investiam boa parte de suas expectativas no apoio dos trabalhistas. Da mesma forma, soa factível que os eleitores de Vargas presentes no comício não votassem necessariamente nos candidatos indicados pelo presidenciável. Isto é, que pode realmente ter havido "apupos" e "assuadas" quando mencionados os nomes de Nereu Ramos e Udo Deeke. No entanto, isso não significa que o comício terminou "friamente" e nem que as pessoas que lá foram apoiavam maciçamente Carlos Gomes de Oliveira e Irineu Bornhausen. Afinal, ao comício de Vargas convergiam eleitores de ambas as facções. Vaias ou aplausos, comuns na ritualística do comício, eram instrumentos da luta política e, certa, foram utilizados pelos grupos que disputavam o executivo estadual durante o meeting com o presidenciável.

Mais do que os eventuais apupos que podem ter acontecido, merece destaque a centralidade da figura do Vargas naquele processo eleitoral. Ao cindir

\footnotetext{
2 "Amigos e trabalhadores de Santa Catarina. Constrangido a entrar na luta política da sucessão presidencial por exigência do povo, para defender altos interesses do país que estão sendo sacrificados apresento-me hoje como candidato, perante o povo catarinense, na sua bela capital. Desejaria ter como meu colaborador no Senado o preclaro brasileiro e meu particular amigo Dr. Nereu Ramos. Ele que na alta função de Vice-Presidente da República foi tão hostilizado pelo atual governo, apesar dos serviços que prestou, bem merece essa reparação. Para governador, recomendo o nome do operoso engenheiro Udo Deeke e para deputados federais e estaduais os candidatos do Partido Trabalhista Brasileiro." VARGAS, 1951).
} 
o PTB, os dois principais partidos de Santa Catarina não brigavam pelos votos da legenda - que as eleições anteriores haviam demonstrado não ser tão expressivo - mas pelo posto de representantes de Getúlio Vargas e o que isso poderia significar em termos eleitorais. Em suma, os partidos acreditavam que o prestígio do ex-presidente, especialmente junto às classes trabalhadoras, poderia ser decisivo nas eleições para o Senado e para o governo do estado.

Os udenistas, a despeito de não abandonarem a candidatura de Eduardo Gomes - e isso pode ser constatado pelas propagandas diárias do candidato no jornal do partido - não desferiram críticas a Getúlio Vargas. Os discursos contra o "estadonovismo" e as acusações de ditador, comuns na campanha de 1945, não foram usados em 1950. (ARAUJO, 2013, p. 19-95). Os ataques se concentraram nas perseguições políticas durante os anos de hegemonia “nereusista" (A TRISTE..., 1950) e na "promiscuidade" do acordo com a cúpula trabalhista em troca do apoio de Vargas para as candidaturas estaduais do PSD (NEREU..., 1950). Ou seja, eram críticas desferidas contra seus adversários locais.

O PSD, também interessado em garantir o apoio do eleitorado varguista, usou o nome do presidenciável para fazer campanha e criticar seu principal rival. O Estado, após o concorrido comício de Getúlio, reproduziu em primeira página o trecho do discurso no qual manifestava o apoio a Nereu Ramos e Udo Deeke (RECOMENDA..., 1950). A UDN não interpretou os acontecimentos do comício da mesma forma. Para o periódico udenista, a fala de Vargas recomendava que o eleitorado votasse livremente nos candidatos do PTB e, "nas entrelinhas do seu discurso", "indicava ao povo que inteligentemente percebeu o nome de Irineu Bornhausen para o governo do Estado, e Carlos Gomes de Oliveira para o Senado e outros candidatos trabalhistas aglutinados nos partidos de oposição em nossa terra." (O QUE..., 1950).

As eleições de 1950 apresentaram uma configuração política diferente do pleito anterior. Nas eleições de 1947, disputava-se quem era o "candidato do povo": Irineu Bornhausen ou Aderbal Ramos da Silva? A chapa de vereadores da UDN ou os candidatos pessedistas à Câmara? Em 1950, a orientação retórica muda. Havia um candidato reconhecidamente popular: Getúlio Vargas. Disputava-se, então, quem atrairia para si este capital político. Para além da 
criatividade nas interpretações do discurso do ex-presidente, acreditava-se que ser reconhecido como "o candidato de Vargas" poderia ser decisivo no pleito. Nesta perspectiva, tanto o PSD quanto a UDN, através dos cortejos aos trabalhistas, buscaram esta identificação.

Todavia, se utilizarmos para a análise apenas o resultado das urnas, concluiremos que a estratégia política adotada pelo PTB local foi bem sucedida. Ao romper com o PSD, a seção catarinense do partido mostrou seu poderio eleitoral ao eleger Vargas ao principal cargo da República, alcançar pela primeira vez uma cadeira no Senado e ajudar a desbancar o domínio político pessedista no estado. Entretanto, a comparação dos dados da eleição presidencial com outros estados da federação e a análise da distribuição dos votos por município indica que, ao menos em Santa Catarina, a candidatura do ex-presidente não teve todo o apelo popular que os estrategistas políticos esperavam.

\section{Nem tão "cristianizado" assim: números da eleição a contrapelo}

No plano nacional, Getúlio foi eleito com 48,7\% dos votos válidos, contra 29,7\% de Eduardo Gomes, 21,49\% de Cristiano Machado e 0,1\% de João Mangabeira (TRIBUNAL SUPERIOR ELEITORAL, 1964). Em Santa Catarina, mesmo com o apoio declarado de Nereu Ramos e dos principais líderes do PSD, Vargas conseguiu somente $40,7 \%$ dos votos. Cristiano Machado, aparentemente relegado pelos caciques pessedistas de Santa Catarina, conseguiu percentual similar ao do plano nacional, 21,9\%. A surpresa foi a votação do Brigadeiro Eduardo Gomes, com 37,4\%, ou seja, apenas três pontos percentuais abaixo do candidato do PTB. O resultado denota o equilíbrio da eleição presidencial no estado em contraste com a euforia getulista das páginas dos periódicos.

Em uma análise comparativa, nos dois outros estados do sul, a distância de Vargas para seus adversários foi supinamente maior. Em sua terra natal, Vargas obteve 49,4\% dos votos, enquanto Eduardo Gomes e Cristiano Machado auferiram 21\% e 29,5\%, respectivamente. No Paraná, o predomínio varguista foi na ordem de 63,8\% do eleitorado, contra 15,6\% e 20,6\% dos candidatos de UDN e PSD, respectivamente. Em São Paulo, maior colégio eleitoral do país, o líder trabalhista praticamente confirmou a tendência da pesquisa de intenção de 
votos realizada pelo IBOPE algumas semanas antes do pleito. ${ }^{13}$ Auferiu 64,3\%, diante de 24,8\% do Brigadeiro e de 10,6\% de Cristiano Machado. Já na capital federal, onde as pesquisas de opinião apontavam equilíbrio entre Getúlio Vargas e Eduardo Gomes ${ }^{14}$, o candidato do PTB conseguiu 65,2\% contra 29,2\% de seu principal adversário. Cristiano Machado ficou com míseros 5,1\% dos votos, bem abaixo de sua média nacional.

É difícil estabelecer as razões da pequena diferença entre Vargas e Eduardo Gomes em Santa Catarina. A escassez de fontes prejudica o mapeamento geográfico da votação dos candidatos. Há, nos arquivos do TRE-SC, a votação dos presidenciáveis por cidade, mas não constam os mapas de apuração por seção eleitoral. Tal cenário torna difícil diagnosticar como votaram os trabalhadores urbanos e, consequentemente, comparar com os números das seções eleitorais localizadas em distritos com predominância de atividades rurais, por exemplo.

O que a análise das votações em Santa Catarina nos permite inferir é que a candidatura de Getúlio Vargas ficou aquém das expectativas geradas pelos periódicos e pelos articuladores de sua campanha. O abandono da candidatura de Cristiano Machado em favor do presidenciável trabalhista - conhecido como “cristianização" - revelou-se também mais ambíguo do que comumente se costuma afirmar ao mencionar o caso catarinense. Pelo fato de o PSD ser liderado por Nereu Ramos, um dos principais prejudicados nas disputas pela sucessão presidencial, é dado como certo que os diretórios pessedistas espalhados pelo estado apoiaram vargas. Todavia, a votação dos candidatos comprovou que este movimento não foi tão coeso quanto se pensou.

A diferença de 3,3\% em favor de Getúlio Vargas significou uma vantagem de apenas 9.012 votos em todo o estado. Uma diferença pequena, especialmente se analisados os números por município. Nos dez maiores colégios eleitorais do

\footnotetext{
${ }^{13}$ A pesquisa apresentava os seguintes números: Getúlio Vargas - 67,2\%; Eduardo Gomes - 21,7\%; Cristiano Machado - 2\%; João Mangabeira - 0,8\% (Instituto Brasileiro de Opinião Pública e Estatística (IBOPE), 1950a, p. 208).

${ }^{14} \mathrm{Em}$ 1949, a pesquisa IBOPE apontava uma vantagem de 2,2\% de Vargas em relação a Eduardo Gomes. Na pesquisa de agosto de 1950, a diferença entre eles aumenta: Vargas - 38,4\%; Eduardo Gomes - 28,8\% (Instituto Brasileiro de Opinião Pública e Estatística (IBOPE), 1950b, p. 189).
} 
Nem tão "cristianizado" assim: apontamentos sobre as eleições de 1950 em Santa Catarina e a vitória de Getúlio Vargas

Camilo Buss Araujo

estado, Vargas venceu em cinco (Florianópolis, Lages, Itajaí, Joinville e Canoinhas), Eduardo Gomes em três (Blumenau, Rio do Sul e Joaçaba) e Cristiano Machado em dois (Chapecó e Tubarão). ${ }^{15}$ Se considerados apenas estes votos, Vargas faria 50.835 sufrágios (46\%), contra 40.621 (36,8\%) de Eduardo Gomes e 18.893 (17,1\%) de Cristiano Machado. ${ }^{16}$ Em números absolutos, a diferença em favor de Vargas seria de 10.214 votos. Mais, portanto, do que a vantagem obtida em todo o estado. Em pontos percentuais, seria de 9,25\%, quase o triplo do obtido no total (TRIBUNAL REGIONAL ELEITORAL DE SANTA CATARINA, 1951).

A vantagem do candidato trabalhista se deu principalmente em três grandes cidades: Canoinhas, Lages e Florianópolis. Em Lages, localizada na serra catarinense e berço político da família Ramos, Vargas obteve a maior votação proporcional: 67,1\% contra 28,6\% e 4,2\% de Eduardo Gomes e Cristiano Machado, respectivamente. Uma diferença de 5.036 votos em relação ao segundo colocado. A expressiva votação de Vargas deixa claro o peso político dos Ramos em sua cidade natal e evidencia ainda mais a orientação de Nereu de solapar a candidatura presidencial de seu correligionário.

Em Florianópolis, no entanto, a conjuntura política foi diferente. A exaltação dos periódicos locais à figura do ex-presidente e a disputa em torno dos significados embutidos no comício sinalizam que o prestígio de Vargas junto aos trabalhadores da capital poderia ser decisivo. Cabe lembrar que Florianópolis fora palco de manifestações queremistas, em 1945, e, nas eleições de janeiro de 1947, as seções eleitorais localizadas no centro deram grande votação às legendas declaradamente ligadas aos trabalhadores, em especial ao PCB (ARAUJO, 2013, p. 19-95).

A vitória de Vargas nos maiores colégios eleitorais contrasta com o desempenho dos oposicionistas nos demais municípios. Ou seja, em que pese a vantagem varguista nas maiores cidades, a UDN conseguiu distribuir melhor a votação do seu presidenciável por todo o estado. O candidato udenista venceu

\footnotetext{
15 Os dez maiores colégios eleitorais de Santa Catarina eram: Florianópolis (23.223 eleitores), Lages (19.221), Chapecó (16.589), Itajaí (15.428), Tubarão (14.704), Joinville (14.254), Blumenau (13.045), Rio do Sul (11.973), Canoinhas (10.507) e Joaçaba (10.379).

16 João Mangabeira fez apenas 27 votos em todo o estado de Santa Catarina. Nos dez maiores municípios, obteve 24 sufrágios.
} 
Nem tão "cristianizado" assim: apontamentos sobre as eleições de 1950 em Santa Catarina e a vitória de Getúlio Vargas

Camilo Buss Araujo

em 25 municípios, Vargas em 22 e Cristiano Machado em cinco. Cabe destacar, no entanto, que estes números não podem ser analisados isoladamente. Em muitos municípios, a diferença entre os candidatos foi de poucos votos. Nas maiores cidades onde o candidato udenista venceu, apenas em Rio do Sul houve uma diferença significativa nos percentuais de votação. ${ }^{17}$ No caso das maiores cidades vencidas por Vargas, houve vantagem expressiva em Florianópolis, Lages e Canoinhas. Em Itajaí e Joinville, apesar de conseguir mais votos que seu adversário, a diferença foi pequena. ${ }^{18}$

Os dados expostos permitem fazer dois apontamentos. O primeiro é sobre o alcance da candidatura de Vargas no interior, em especial nos municípios menores. O segundo, que nada mais é do que uma extensão do primeiro, é sobre as ambiguidades do processo de "cristianização" da candidatura oficial pessedista em Santa Catarina. Ambos possibilitam uma reflexão sobre a estratégia política do PTB local e as incoerências que permearam o pleito de 1950.

Era público e manifesto que o principal interesse do PTB era eleger Vargas presidente da República. Para tanto, e esse aspecto já foi previamente mencionado, era necessário ampliar ao máximo a base de apoio do presidenciável nos estados. Mais do que estabelecer alianças ideológicas ou restringir-se às coligações oficiais, urgia ser pragmático. O PSD, maior partido do país, criado com a "benção" do ex-presidente, seria um aliado estratégico. Possuía uma máquina eleitoral ampla e capilar capaz de, no caso catarinense, atuar com cabos eleitorais nos rincões dificilmente acessíveis aos candidatos. Entretanto, as disputas internas no PTB e a dupla posição no pleito - uma parte seguindo as orientações do diretório nacional de apoio a Nereu Ramos e Udo Deeke e outra com Carlos Gomes e Irineu Bornhausen - fragilizaram sua

\footnotetext{
17 Em Blumenau, a vantagem de Eduardo Gomes foi de 1,6\% (44,7\% versus 43,1\%), uma diferença de apenas 146 votos (4.290 contra 4.144). Em Joaçaba, o Brigadeiro fez 38,2\% contra 35,9\% de Vargas, uma diferença de 182 votos (3.003 contra 2.821). Apenas em Rio do Sul a diferença foi mais expressiva, 50,5\% para o Brigadeiro contra 38,2\% de Vargas, vantagem de 1.082 votos (4.420 contra 3.338)

${ }^{18}$ Em Itajaí, Vargas venceu o candidato udenista por 4 pontos percentuais (45\% contra 41\%), uma diferença de 445 votos (5.089 contra 4.644). Em Joinville, a diferença pró-Vargas foi de apenas 1,8\% (47,7\% contra 45,9\%), 5.282 votos contra 5.089. Destaca-se a votação obtida em Canoinhas, onde o candidato trabalhista conseguiu uma vantagem de 28,7\% (57,7\% contra 29\%), 4.147 votos contra 2.089 de Eduardo Gomes.
} 
candidatura presidencial. Ao menos a comparação entre a votação de Vargas e a euforia getulista presente na imprensa da capital indicam isso. A questão, todavia, ainda merece ser mais bem elucidada.

Gráfico 1: Votação dos candidatos à presidência da República em Santa Catarina

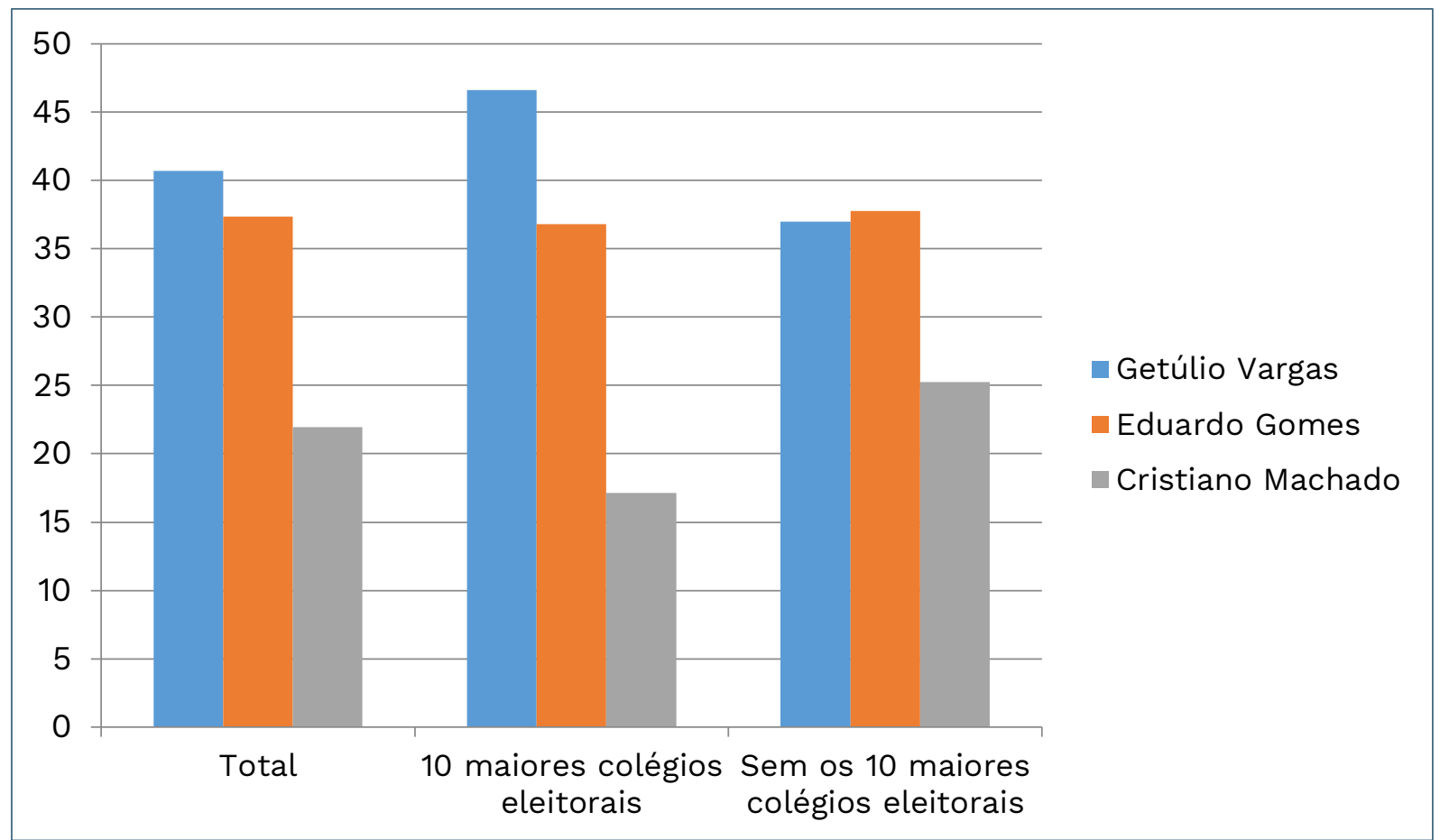

Fonte: TRIBUNAL REGIONAL ELEITORAL DE SANTA CATARINA, 1951.

Se desconsiderássemos os dez maiores colégios eleitorais do estado, Eduardo Gomes teria sido o mais votado, 1.202 votos a frente a vargas (37,75\% contra 37\%). Surpreende, contudo, a votação de Cristiano Machado. O candidato pessedista, nas menores cidades, fez 25,23\% dos votos. Ou seja, acima do percentual obtido no plano nacional. Ademais, ao compararmos a votação das dez maiores cidades com as demais, veremos que Eduardo Gomes mantém-se estável - oscila menos de um ponto percentual (36,8\% nas maiores e 37,75\% nas demais). Logo, a perda de nove pontos percentuais de Vargas nos menores municípios (46\% contra 37\%) dá-se em função do crescimento proporcional da votação de Cristiano Machado (17,1\% e 25,2\%). Com base nestes dados, há fortes indícios de que a candidatura de Vargas encontrou dificuldades flagrantes de penetração nos pequenos municípios. Neste sentido, parte da explicação, acredito, reside na estratégia eleitoral dos trabalhistas no estado e, consequentemente, no papel desempenhado pelo seu aliado não oficial: o PSD. 
Nem tão "cristianizado" assim: apontamentos sobre as eleições de 1950 em Santa Catarina e a vitória de Getúlio Vargas

Camilo Buss Araujo

As pretensões do comando nacional petebista - de aliança com o PSD em Santa Catarina - esbarraram na desobediência dos dirigentes regionais. Ao arquitetar a aliança com a UDN, O PTB catarinense construiu um complicado cenário político para a candidatura de Vargas. Por um lado, esperava-se o apoio dos partidários de Nereu Ramos a Getúlio em virtude dos desarranjos internos no PSD envolvendo a sucessão presidencial. E é evidente que a força do maior partido do estado seria mais sensível no interior, onde o PTB tinha dificuldades de se estabelecer e a máquina eleitoral pessedista chegava com força. ${ }^{19}$ Por outro lado, a campanha trabalhista pró-Vargas vinha associada ao apoio ao também trabalhista Carlos Gomes de Oliveira para o Senado. Consequentemente, contra Nereu Ramos, seu adversário no pleito. Por fim, além de proclamar nos palanques o apoio a Getúlio e a Carlos Gomes, o PTB também fazia campanha para o udenista Irineu Bornhausen para o governo. Logo, contra o pessedista Udo Deeke. Ou seja, ao percorrer o estado, a campanha trabalhista combinava os discursos de apoio a Vargas com críticas ao situacionismo representado pelo PSD.

É crível inferir, diante desta situação, que a adesão dos líderes pessedistas locais ao candidato do PTB não seria automática. O apoio seria dado mediante o cálculo dos benefícios políticos que ele poderia render. Diante disso, surgem as questões: se o prestígio de Vargas assentava-se principalmente junto aos trabalhadores urbanos, qual o interesse dos líderes pessedistas do interior do estado em abandonar a candidatura oficial e fazer campanha para o candidato trabalhista?20 Em outras palavras, para os "caciques" pessedistas do interior do estado, seria politicamente vantajoso vincular-se ao nome do ex-presidente? Sobretudo com o PTB apoiando seus rivais históricos para o governo do estado e para o Senado? É possível tecer algumas considerações sobre essas questões a partir da análise da votação em algumas cidades do estado.

\footnotetext{
19 Podemos observar este aspecto nas eleições para o governo do estado ocorridas em 1947. Em Florianópolis, o PSD obteve ampla maioria de votos nas seções eleitorais localizadas em localidades de predomínio das atividades rurais. Na região central, onde votava a maior parte dos trabalhadores urbanos, os resultados eram incertos e, naquele pleito, Irineu Bornhausen foi o mais votado. (ARAUJO, 2013, p. 19-95).

${ }^{20}$ Exemplo da força de Getúlio junto aos trabalhadores urbanos pode ser visto no estudo de John French, ao analisar como, em Santo André, no ABC paulista, cidade predominantemente operária, Getúlio fez 84\% dos votos. (FRENCH, 1995, p. 254).
} 
Em Chapecó, município no extremo oeste de Santa Catarina e terceiro maior colégio eleitoral do estado, Cristiano Machado venceu as eleições presidenciais com 42,6\% dos votos. Incorporado em 1946 ao estado de Santa Catarina, Chapecó era um município extenso, que englobava vários outros distritos. ${ }^{21}$ Com a redemocratização, formaram-se os três principais partidos da cidade: PSD, UDN e PTB. No entanto, os dois últimos foram criados como dissidências do primeiro, decorrentes mais de divergências pessoais do que programáticas. Isso, segundo Hass, fez com que mesmo a UDN, construída nacionalmente para fazer oposição ao getulismo, fosse, em Chapecó, formada por elementos ligados ao governo Vargas (HASS, 1993, p.155).

Na eleição de 1950, a UDN e o PTB local uniram forças para suplantar o predomínio pessedista. Montou-se uma coligação com UDN, PTB, PRP e PSP, lançando o trabalhista José de Miranda Ramos para prefeito. De acordo com Hass, as plataformas de campanha dos oposicionistas eram a autonomia dos distritos e o "programa trabalhista", onde aparecia o tema da reforma agrária (HASS, 1993, p.155). Nesse caso, as articulações em torno da disputa pelo executivo municipal, de certa forma, contribuíram para definir os posicionamentos dos partidos locais na disputa estadual e nacional. Os grupos apoiadores do candidato trabalhista traziam consigo parte dos discursos de Getúlio Vargas, além do delicado tema da distribuição de terras. Já os pessedistas, cuja base da atividade econômica estava ligada às grandes propriedades rurais e à indústria madeireira, cerraram fileiras na disputa pelo executivo local e apoiaram o nome de Cristiano Machado no pleito presidencial.

Na eleição para prefeitura de Chapecó, o vitorioso foi José de Miranda Ramos do PTB. Entretanto, o PSD local mostrou sua força elegendo sete dos onze vereadores e fazendo com que Cristiano Machado fosse o presidenciável mais votado (42,6\%). Vargas ficou em segundo, com 36,6\% dos votos, e Eduardo Gomes em terceiro, com 20,7\% (TRIBUNAL REGIONAL ELEITORAL DE SANTA CATARINA, 1951, p. 2, 3, 9-33). Ao reagir às plataformas trabalhistas veiculadas na

\footnotetext{
${ }^{21}$ Antes de fazer parte de Santa Catarina, Chapecó pertencia ao Território Federal do Iguassu. Sua área compreendia toda a parte oeste do estado. Alguns dos distritos que compreendiam a área do município emanciparam-se entre 1951 e 1956, tais como: Mondaí, Dionísio Cerqueira, Palmitos, São Carlos, Xaxim e Itapiranga (GOVERNADORES, 1993, p. 74).
} 
campanha oposicionista, o PSD chapecoense combateu a candidatura de Vargas e, portanto, não promoveu a "cristianização" do seu candidato oficial.

É importante destacar este aspecto, visto que, na maioria das vezes, explica-se o fracasso da candidatura de Cristiano Machado pela infidelidade de seus correligionários nos estados. Em Santa Catarina, pelo fato de ser o reduto político de Nereu Ramos, um dos mais prejudicados pelas articulações que deliberaram o candidato pessedista à presidência, incorre-se no equívoco de pensar que houve uma adesão harmônica e generalizada do PSD à candidatura de Getúlio Vargas. Não foi o que aconteceu. A despeito da orientação de seu principal líder, os diretórios pessedistas do interior não apoiaram maciçamente o candidato trabalhista. A perda de nove pontos percentuais na votação de Vargas nos municípios menores e o avanço da votação de Cristiano Machado na mesma proporção sinaliza que a adesão dos diretórios do PSD do interior à candidatura do líder trabalhista estava relacionada às disputas locais e dependia de um cálculo político sobre os benefícios eleitorais que poderiam ser obtidos.

\section{Considerações finais: o pragmatismo político da UDN e a vitória eleitoral}

Parece claro que as brigas viscerais dentro do PTB catarinense prejudicaram a candidatura de seu líder maior. As acusações mútuas veiculadas cotidianamente nos principais jornais de Florianópolis enterraram definitivamente uma desejada "unidade partidária" no estado. Os trabalhistas, ao se coligarem com a UDN - que fez campanha para Eduardo Gomes - perderam o apoio de parte do PSD.

A cisão petebista não foi a única daquele pleito. O PSD, silenciosamente, também cindiu. A posição ambígua na sucessão presidencial atrelada à aliança entre udenistas e trabalhistas tornou sua campanha confusa: parte do partido apoiava Vargas e parte apoiava Cristiano Machado. Ao mesmo tempo, ao fazer campanha para Nereu Ramos para o Senado, atacava seu concorrente, o trabalhista Carlos Gomes de Oliveira - que se intitulava "o legítimo representante de Vargas no estado". A UDN, por sua vez, mais organizada do que nas eleições anteriores, aproveitou-se da posição vacilante do PSD e firmou sua chapa com 
Eduardo Gomes, Irineu Bornhausen e Carlos Gomes de Oliveira. Conquistou o executivo estadual, desbancou Nereu Ramos, seu maior inimigo, e alavancou uma votação significativa para seu candidato a presidente. Nas eleições municipais, conquistou o maior número de prefeituras. Elegeu 25 prefeitos, cinco em coligação com o PTB. O PTB elegeu dois. O PSD, com 23 prefeitos eleitos, perdia sua supremacia política. ${ }^{22}$

Os resultados de 1950 fazem lembrar a expressão de um eminente udenista catarinense, durante a convenção da UDN, em 1946. Bulcão Viana pediu a palavra para transmitir o seguinte recado aos seus correligionários: "governo é governo enquanto o povo o quiser." (ECOS..., 1946). A frase de efeito simbolizava as aspirações dos oposicionistas em assumir o poder. Entretanto, o partido foi derrotado tanto na eleição de janeiro quanto na de novembro de 1947. Para o pleito de 1950, os udenistas reinterpretaram a frase de seu correligionário e foram pragmáticos: flexibilizaram o discurso e disputaram o eleitorado varguista. Já o PTB catarinense contrariou as orientações nacionais e apoiou Irineu Bornhausen. Esfacelou-se internamente e jogou água nas pretensões de seu candidato presidencial de contar com a adesão maciça do PSD no estado. Lançaram-se os dados e a oposição venceu. A UDN, autointitulada como "partido dos homens de bem" e "partido das elites", juntou-se ao PTB e mirou o trabalhador. O grupo de Nereu Ramos, após quase duas décadas, perdia o controle do estado. Mas a alternância de poder não era a única mudança encetada nos anos 1950.

Os resultados eleitorais construíam um novo organograma político em Santa Catarina. UDN e PTB concretizavam uma bem-sucedida aliança que os alçara ao controle do executivo estadual. Contudo, a aparente harmonia no plano regional contrastaria com a postura das direções nacionais das legendas. Vargas assumia a presidência da República sob protestos de udenistas e de parte da imprensa. O PSD nacional pleiteava cargos no novo governo enquanto a seção catarinense rearranjava-se após a dolorosa derrota. Compunha-se um frágil mosaico político, repleto de incoerências, que as crises ao longo do segundo governo de Vargas tratariam de desestabilizar.

\footnotetext{
22 Em 1950, não havia eleição para prefeito nas cidades de Florianópolis e São Francisco do Sul. Consideradas estratégicas, seus prefeitos eram nomeados pelo governador.
} 


\section{Referências}

A CHEGADA do Sr. Getúlio Vargas e uma vibrante lição do povo. Diário da Tarde, Florianópolis, 21 set. 1950.

A TRISTE história de duas traições. Diário da Tarde, Florianópolis, 22 set. 1950.

A VERDADE sobre o acordo do PTB com a UDN em S. Catarina. O Estado, Florianópolis, 14 set. 1950.

APELO aos srs. Empregadores. O Estado, Florianópolis, 19 set. 1950.

ARAUJO, Camilo Buss. Marmiteiros, agitadores e subversivos: política e participação popular em Florianópolis, 1945-1964. Campinas, 2013. 492 f. Tese (Doutorado em História Social) - Programa de Pós-Graduação em História Social, Universidade Estadual de Campinas.

BENEVIDES, Maria Victória de Mesquita. A UDN e o udenismo: ambiguidades do liberalismo brasileiro (1945-1965). Rio de Janeiro: Paz e Terra, 1981.

CADÊ os documentos. O Estado, Florianópolis, 12 set. 1950.

COM IRINEU Bornhausen, as oposições coligadas. Diário da Tarde, Florianópolis, 07 set. 1950.

CRISTIANO Machado visita Santa Catarina. Diário da Tarde, Florianópolis, 13 set. 1950.

D’ARAUJO, Maria Celina. O segundo governo Vargas (1951-1954). 2 ed. São Paulo: Ática, 1992.

DELGADO, Lucília de Almeida Neves. PTB: do Getulismo ao Reformismo (19451964). 2 ed. São Paulo: LTr, 2011.

DESLUMBRANTE a recepção do povo a Getúlio Vargas. A Gazeta, Florianópolis, 20 set. 1950.

DIÁRIO DA TARDE. Florianópolis, 25 jul. 1950.

DUARTE, Adriano Luiz. Cultura popular e cultura política no após-guerra: redemocratização, populismo e desenvolvimentismo no bairro da Mooca, 19421973. Campinas, 2002. 273 f. Tese (Doutorado em História) - Instituto de Filosofia e Ciências Humanas, Universidade Estadual de Campinas. 
ECOS da Convenção da União Democrática Nacional em Santa Catarina. Diário da Tarde, Florianópolis, 26 nov. 1946.

ESSES “amigos” do trabalhador. O Estado, Florianópolis, 06 ago. 1950.

FALA-NOS o Dr. Carlos Gomes de Oliveira. Diário da Tarde, Florianópolis, 12 set. 1950.

FRENCH, John D. O ABC dos operários: conflitos e alianças de classe em São Paulo, 1900-1950. São Paulo/São Caetano do Sul: Hucitec/Prefeitura de São Caetano do Sul, 1995.

GETÚLIO teve recepção consagradora em Santa Catarina. O Estado, Florianópolis, 20 set. 1950.

GOVERNADORES de Santa Catarina. Diário Catarinense, Florianópolis, 25 nov. 1993. Suplemento especial.

GRANDE manifestação de simpatia e solidariedade. Diário da Tarde, Florianópolis, 15 set. 1950.

HASS, Monica. Os partidos políticos e a elite chapecoense. Um estudo do poder local. 1945 a 1965. Florianópolis, 1993. 361 f. Dissertação (mestrado em Sociologia Política) - Centro de Filosofia e Ciências Humanas, Universidade Federal de Santa Catarina.

HIPPÓLITO, Lúcia. De raposas e reformistas: O PSD e a experiência democrática brasileira (1945-1964). Rio de Janeiro: Paz e Terra, 1985.

INSTITUTO BRASILEIRO DE OPINIÃO PÚBLICA E ESTATÍSTICA (IBOPE). Pesquisa de intenção de voto para presidente da República em 1950, realizada em junho de 1949. [S.L.]: Acervo do Arquivo Edgard Leurenroth (AEL), 1949. Fundo IBOPE, filme MR/256, P 08 .

INSTITUTO BRASILEIRO DE OPINIÃO PÚBLICA E ESTATÍSTICA (IBOPE). Pesquisa de opinião pública sobre matéria política realizada pelo IBOPE no período de 6 a 15 de setembro de 1950, na capital de São Paulo. [S.L.]: Acervo do Arquivo Edgard Leurenroth (AEL), 1950a. Fundo IBOPE, filme MR/256, PE 09.

INSTITUTO BRASILEIRO DE OPINIÃO PÚBLICA E ESTATÍSTICA (IBOPE). Pesquisa política, levada a efeito, no Rio de Janeiro, durante o mês de agosto de 1950. [S.L.]: Acervo do Arquivo Edgard Leurenroth (AEL), 1950b. Fundo IBOPE, filme MR/256, PE 09.

INTERVENÇÃO no PTB catarinense. Diário da Tarde, Florianópolis, 14 set. 1950. 
LAMARÃO, Sérgio. O fracasso das "fórmulas" e a candidatura Vargas em 1950.

[S.l.: CPDOC], [20--]. Disponível em: http://cpdoc.fgv.br/producao/dossies/ AEraVargas2/artigos/PreparandoaVolta/Candidatura1950. Acesso em 13 de dezembro de 2011.

MENDONÇA, Marina de Gusmão. O demolidor de presidentes: a trajetória política de Carlos Lacerda: 1930-1968. São Paulo: Codex, 2002.

MOREIRA, Regina da Luz. Vargas: o parlamentar ausente e as articulações do exílio. [S.l: CPDOC], [2-0--]. Disponível em:

http://cpdoc.fgv.br/producao/dossies/

AEraVargas2/artigos/PreparandoaVolta/Parlamentar Ausente. Acesso em 13 dez. 2011.

NÃO é verdade. A Gazeta, Florianópolis, 05 jul. 1950.

NÃO há documentos. O Estado, Florianópolis, 13 set. 1950.

NEREU, que é PSD, aconselhará eleitorado a votar em Getúlio Vargas. Diário da Tarde, Florianópolis, 22 set. 1950.

OLIVEIRA, Lisandre Medianeira. O PSD no Rio Grande do Sul: o diretório mais dissidente do país nas "páginas" do Diário de Notícias. Porto Alegre, 2008. 270 f. Tese (Doutorado em História). Pontifícia Universidade Católica do Rio Grande do Sul.

O ESTADO. Florianópolis, 07 set. 1950a.

O ESTADO. Florianópolis, 13 set. 1950b.

O ESTADO. Florianópolis, 19 set. 1950c.

O PTB e o PSD em chapa única. A Gazeta, Florianópolis, 13 set. 1950.

O QUE foi a indicação de Getúlio Vargas. Diário da Tarde, Florianópolis, 22 set. 1950.

OPERÁRIO. O Estado, Florianópolis, 4 ago. 1950.

PARTIDO Social Democrático. O Estado, Florianópolis, 12 set. 1950.

PTB. A Gazeta, Florianópolis, 20 ago. 1950. 
RECOMENDA, Getúlio Vargas, nesta capital, a candidatura de Udo Deeke. O Estado, Florianópolis, 21 set. 1950.

REPETIU, mas não repetirá. O Estado, Florianópolis, 10 set. 1950.

SAMPAIO, Regina. Adhemar de Barros e o PSP. São Paulo: Global, 1982. p. $135-$ 139.

SENSACIONAL. A Gazeta, Florianópolis, 12 set. 1950.

TELEGRAMA circular que a Comissão Diretora do Partido Trabalhista Brasileiro, secção de Santa Catarina, expediu aos Diretórios Municipais. O Estado, Florianópolis, 16 set. 1950.

TRIBUNAL SUPERIOR ELEITORAL. Dados Estatísticos: eleições federais e estaduais realizadas no Brasil em 1950. v. 2. [S.l.]: Departamento de Imprensa Nacional, 1964.

VARGAS, Getúlio. A campanha presidencial. São Paulo: J. Olympio, 1951. 